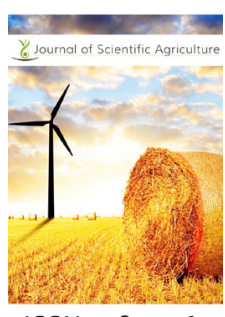

ISSN: $2184^{-0} 0261$

\title{
Determining genetic diversity of deshi jute (Corchorus capsularis) for the improvement of fibre yield and associated traits
}

\author{
Arju Miah*, A. K. M. Shahadat Hossain', Nihar Ranjan Saha², \\ Md. Younus Ali3, Md. Jahangir Alam', Sayma Farabi²
}

\begin{abstract}
${ }^{1}$ Genetic Resources and seed Division, Bangladesh Jute Research Institute, Manik Mia Avenue, Dhaka - 1207, Bangladesh, '2Department of Biotechnology, Bangladesh Agricultural University, Mymensingh-2202, ${ }^{3}$ Fibre Quality Improvement Division, Bangladesh Jute Research Institute, Manik Mia Avenue, Dhaka - 1207, Bangladesh
\end{abstract}

Received: July 08, 2020 Accepted: July 31, 2020 Published: August 03, 2020

*Corresponding author: Arju Miah, arjumia146@gmail.com

\begin{abstract}
Commercially important natural fibres considered as fiber of the future are cultivated in different south-east Asian countries including India and Bangladesh. Unfortunately, they are characterized by limited genetic variation in terms of yield, quality and susceptibility to diseases and pests. Therefore, genetic deviation studies are crucial to develop a successful cultivation program to develop varieties to meet the growing demand for domestic and foreign jute products. This was conducted at the Central Jute Research Experiment Station of Bangladesh Jute Research Institute (BJRI), during Kharif seasons of 2014. 44 Thirteen progenies (1546, 1548, 4311, 4328, 4330, 4337, 4339, 5007, 6702/A, 6702/B, 6772, 6787, 6790) and two check varieties CVL-1 and CVE-3 (developed from Bangladesh Jute Research Institute) were investigated to study the genetic variability, genetic diversity and degree of association of different component characters related to fiber yield. The seeds of experimental plant materials were grown in Randomized Complete Block Design with three replications. Statistical analysis was run to find out the genotypic and phenotypic variances, correlations and cluster analysis for fibre yield related traits namely plant height $(\mathrm{m})$, base diameter (cm), stick weight $(\mathrm{g})$, fiber weight $(\mathrm{g})$. Highly significant differences were observed among the genotypes for all the characters. Cluster analysis divided the accessions and varieties into four cluster. From our evaluation it was revealed that the treatment number 4337/06, 4339/06 and 6702/A performed better in most of the cases than the control varieties CVL-1 and CVE-3. These accessions may be used as parents for future variety development program.
\end{abstract}

KEYWORDS: Genetic divergence, cluster analysis, bast fibre, fibre yield, deshi jute

\section{INTRODUCTION}

Various types of natural fibers have been important for humanity for centuries. Invented in the twentieth century, plastic and synthetic fibers led to the production of many types of polymer composites reinforced with synthetic fibers, which are now widely used in everyday life. However, such synthetic materials are largely produced from non-renewable sources, so the use of plant fibers in composites (known as bio-based composites) is interesting. This depends not only on their ecological and sustainable aspects, but more importantly on their performance and costs.

Jute is a member of the Corchorus genus in the Tiliaceae family and is second to cotton in its commercial importance in the world. The genus Corchorus (Jute) consists of about 50-60 species distributed in the tropics, subtropics and warm temperate regions of the world $[1,2,3,4]$. Jute cultivation is believed to have started 200 years ago in the tropics [5]. It is mainly distributed in China, India, Bangladesh and east-central Africa, where it has been grown for several thousand years for natural fiber production [6,7]. White jute (C. capsularis) and dark jute (C. olitorius) are two most popular cultivated Corchorus species. Both species have $2 \mathrm{n}=2 \times=14$ chromosomes [8]. Although it is not known how both cultivated jute species emerged, they differ in habitat, disease resistance and flowering-related properties and silica form [9]. For example, the white jute silhouette is round and the dark jute is long. In addition, the two cultivated species are incompatible, possibly due to the presence of the sexual incompatibility barrier [6].

Jute is important for the textile and paper industries because it is a valuable ingredient for the production of paper and

Copyright: ๑) The authors. This article is open access and licensed under the terms of the Creative Commons Attribution License (http://creativecommons.org/licenses/by/4.0/) which permits unrestricted, use, distribution and reproduction in any medium, or format for any purpose, even commercially provided the work is properly cited. Attribution - You must give appropriate credit, provide a link to the license, and indicate if changes were made. 
quality textiles as well as a renewable source of biofuels [10]. Jute fibers characteristically show high gloss, good moisture absorption performance, rapid dehydration capacity and easy degradation [11]. Unlike heavy cotton requirements, jute is a rain-fed product that needs little fertilizer or insecticide. Production mainly concentrates in Bangladesh and India, almost $85 \%$ of world jute farming in this area (www.jutecomm.gov.in. 2014). Total global jute production is 339.3 million tons and only Bangladesh produced 145.2 million tons and represents $41.9 \%$ of the total [12]. In Bangladesh, 737,770 hectares of hectares are grown for jute, and the yield per hectare is 11,178 bales, and the total production is 8246797 bales [13].

Bangladesh is the homeland of quality jute production. Once upon a time it was the principle exporting goods of Bangladesh. Most of foreign currency was earned from this sector before liberation and it was sold as raw and finished goods. Not only its golden color but also its currency earning gives it the name Golden Fibre. Then, due to several factors including increased use of artificial fibres and low jute prices farmers found less incentive to grow jute. Many jute mills were forced to close, with jute production on the verge of extinction. At present, Bangladesh is trying to decrease this lack of demand to a huge extent by imposing the mandatory Jute Packaging Act, 2010 on a wide array of products, recently including 12 new products along with the six existing ones (Source: The Independent, Feb 11, 2014). According to the jute department, one bale of jute produces around 238 pieces of jute sacks, each of which holds around $50 \mathrm{~kg}$ of any item. So, it can be assumed that this will increase the domestic demand for jute bales by around 1.23 million and of jute sacks by around 300 million. An immediate amicable solution is needed to enlarge the export jute market of Bangladesh. The country has yet to tap the market of jute composites which is globally flourishing (US $\$ 6.5$ billion by 2021) (The Financial Express 3 May, 2017).

Bangladesh Jute Research Institute (BJRI) has established a gene bank in 1982 now having world's largest collection of about 6060 accession of jute and allied fiber (JAF) germplasm from home and abroad [14]. Since jute is a largely self-pollinated product, its natural genetic variations are very limited, making it difficult for growers to develop new varieties of this crop through traditional breeding. The presence of genetic variation in a group of genes is the main problem of an improvement program. Assessment of genetic variation using appropriate parameters such as genotypic coefficient of variation, heredity and genetic progression is essential for starting an effective breeding program. In addition, heredity knowledge is crucial for selection-based improvement, as it shows the degree of transferability of a character to future generations [15]. Genetic progress provides information about the expected genetic gain from the selection of superior individuals [16]. High inheritance and high genetic development estimates are more useful than prediction of inheritance alone to predict earnings under selection [17].

Genetic diversity is a key factor in the effective selection of parents for the diversity development program. Genetic diversity can be investigated by morphological and reproductive functions. The diversity study in specimen collection is crucial for the identification of new genes and further development of bacterial plasma [18]. So, in order to develop high yielding varieties coupled with quality fibre, early maturity, wide adaptability, disease and pest tolerance, the promising varieties/ lines were crossed in all possible combinations to complete the $10 \times 10$ parents diallel set during 1999-2000. Their $\mathrm{F}_{2}$ and subsequent generations were raised for selection superior lines/ plants according to desirable traits. Objective of this experiment was to develop high yielding lines by field evaluation of 13 promising lines with the studies and selection of desirable progenies.

\section{MATERIALS AND METHODS}

The experiment was carried out at the Jute Agricultural Experiment Station of Bangladesh Jute Research Institute (BJRI), Jagir, Manikgonj during the period from April to August, 2014.

\section{Experimental Site}

The experimental site was situated at 23053.95 "N latitude and 90004" E longitude with an elevation of $8.8 \mathrm{~m}$ from the sea level.

\section{Climate and Soil}

The experimental site was situated in the tropical climate zone, characterized by heavy rainfall during the month from May to September and scantly rainfall during rest of the year. The soil of the experimental field was sandy loam in texture having $\mathrm{pH}$ around 6.5 to 7.5 . It belongs to the young Brahmaputra and Jamwia Floodplain Agro Ecological Zone. The land was medium high with uniform topography and almost homogenous with respect to soil fertilizer.

\section{Experimental Material}

The material comprised of thirteen progenies of white jute (C. cupsularis) including two check varieties CVL-1 and CVE3. The genetically pure and physically healthy seeds of these genotypes were collected from the gene bank of Bangladesh Jute Research Institute (BJRI). Dhaka. Detailed of 13 progenies with two check varieties is given in Tablel.

\section{Design and Layout}

The experiment was laid out in a Randomized Complete Block Design (RCBD) with three replications. Each plot had a single row of $3.6 \mathrm{~m}$ length. Space between rows was $0.30 \mathrm{~m}$ and block to block distance was $1.0 \mathrm{~m}$. The genotypes were randomly distributed to each row with in each block.

\section{Harvesting}

These genotypes were harvested within 110 days after planting, just before pods develop. Selected plants (1.5-4.0 m tall) were pulled from soil with roots, washed and tied in bundles with a 
tag. Harvesting was done during the cooler time of day, such as early morning or late afternoon, and kept in cool and shaded place.

\section{Data Analysis}

Analysis of variance and covariance were done according to Aljibouri, et al., (1998) [19]. Coefficient of variation (PCV and GCV) and heritability (H2b) were calculated by the formulae suggested by Burton (1952) [20] and Hanson et al., (1956) [21], respectively. Genetic advance (GA) was derived by the formula given by Johnson, et al., (1955) [22]. A cluster diagram was drawn according to Singh and Chaudhury (1985) [23] that gave a brief idea of the pattern of diversity among the genotypes included in a cluster.

\section{RESULTS}

Observations were recorded from ten plants selected randomly ftom each replication for the four fibre yield related traits namely plant height $(\mathrm{m})$, base diameter ( $\mathrm{mm})$, fibre weight/ plant (g), stick weight/ plant (g). Simple correlation coefficients were obtained between all possible combinations of characters related to fibre yield. Fibre yield was considered as the resultant (dependent) variable.

A total of 15 accessions and varieties were collected from Bangladesh Jute Research Institute (BJRI), were phenotypically evaluated for fibre yield and other Attributing Traits.

The analysis of variance (ANOVA) showed that the accessions had significant or very significant differences for all the studied characteristics, viz., plant height ( $\mathrm{m})$, base diameter ( $\mathrm{mm})$, fibre weight/ plant $(\mathrm{g})$, stick weight/ plant $(\mathrm{g})$. (Table 2).

The mean performance of four important yield attributing character of 13 advanced lines with two check varieties are represented in the table 3.

From the investigation, we have found that genotypes ranged from 2.50 to $3.12 \mathrm{~m}$ for plant height (Table 3). Treatment $6787 / 07$ gave highest plant height of $3.12 \mathrm{~m}$, which was followed by $4330 / 08$ that produced $2.96 \mathrm{~m}$. The lowest plant height was given by the treatment 4328/06. While two check varieties, CVL-1 and CVE-3 heighted 2.73 and 2.68 respectively. The check variety CVL-1 produced highest base diameter of $20.32 \mathrm{~mm}$, which was then followed by the treatment 6702/A and 6772/07 having 20.31 and $20.26 \mathrm{~mm}$ of base diameter respectively. Among them the treatments 4337/06 and 4339/06 gave better stick weight/plant than that of the check varieties. The highest stick weight/plant was produced 21.12 and $20.23 \mathrm{~g}$ respectively. . In case of fibre yield/plant, the treatment 4337/06 produced highest yield of $9.89 \mathrm{~g}$. Which was followed by, 4339/06 and 6702/A having fibre weight/plant of 9.70 and $9.21 \mathrm{~g}$ respectively. Contrariwise, the two check varieties, CVL-1 and CVE-3 gave 8.80 and $8.78 \mathrm{~g}$ fibre weight/plant. Similar findings was observed by Arju Miah., et al 2020 [24].
Table 1: Details of released varieties of white jute (Corchorus capsularis L.) in Bangladesh

\begin{tabular}{llc}
\hline Treatment & Parentage & Pedigree \\
\hline $1546 / 08$ & Acc. $1832 \times$ Var. CC-45 & $9945-1-1546 / 08$ \\
$1548 / 08$ & Acc. $1832 \times$ Var. CC-45 & $9945-3-1548 / 08$ \\
$4311 / 06$ & Var. A-38 $\times$ Acc. 1832 & $9977-1-4311 / 06$ \\
$4328 / 06$ & Var. A-38 $\times$ Acc. 1832 & $9977-2-4328 / 06$ \\
$4330 / 08$ & Var. A-38 $\times$ Acc. 1832 & $9977-3-4330 / 08$ \\
$4337 / 06$ & CVL-1 $\times$ Acc. 1831 & $993-4-4337 / 06$ \\
$4339 / 06$ & Acc. $1831 \times$ Var. A-38 & $9935-1-4339 / 06$ \\
$5007 / 07$ & Acc. $1515 \times$ Var. CVL-1 & $9919-2-5007 / 07$ \\
$6702 / A$ & Var. CVL-1 $\times$ Acc. 1831 & $993-3-6702 / A$ \\
$6702 / B$ & Var. CVL-1 $\times$ Acc. 1831 & $993-3-6702 / B$ \\
$6772 / 07$ & Var. A-38 $\times$ Acc. 1832 & $9977-1-6772 / 07$ \\
$6787 / 07$ & Acc. $4087 \times$ Acc. 1831 & $9967-1-6787 / 07$ \\
$6790 / 06$ & Acc. $1831 \times$ Acc.1832 & $9961-2-6790 / 06$ \\
CVL-1 & - & \\
CVE-3 & - & \\
\hline
\end{tabular}

Table 2: Analysis of variance (mean square) of different deshi jute progenies for yield attributing characters.

\begin{tabular}{lccccc}
\hline $\begin{array}{l}\text { Source of } \\
\text { variation }\end{array}$ & df & $\begin{array}{c}\text { Plant } \\
\text { height } \\
(\mathrm{m})\end{array}$ & $\begin{array}{c}\text { Base } \\
\text { diameter } \\
(\mathrm{mm})\end{array}$ & $\begin{array}{c}\text { Fibre weight/ } \\
\text { plant }(\mathrm{g})\end{array}$ & $\begin{array}{c}\text { Stick weight/ } \\
\text { plant }(\mathrm{g})\end{array}$ \\
\hline Replication & 2 & 0.004 & 0.058 & 0.002 & 0.391 \\
Accessions & 14 & $0.078^{* *}$ & $0.311^{*}$ & $1.104^{* *}$ & $4.354^{* *}$ \\
Error & 28 & 0.008 & 0.140 & 0.029 & 0.217 \\
\hline ** = Significant at 1\% level of probability, * = Significant at 5\% level \\
of probability
\end{tabular}

Table 3: Mean performance for different fibre yield related traits of different deshi jute progenies

\begin{tabular}{|c|c|c|c|c|}
\hline Accessions & $\begin{array}{c}\text { Plant } \\
\text { height (m) }\end{array}$ & $\begin{array}{l}\text { Base diameter } \\
\text { (mm) }\end{array}$ & $\begin{array}{l}\text { Fibre weight/ } \\
\text { plant }(\mathrm{g})\end{array}$ & $\begin{array}{c}\text { Stick weight/ } \\
\text { plant (g) }\end{array}$ \\
\hline $1546 / 08$ & $2.58^{g h}$ & $19.63^{a-c}$ & $8.46^{\mathrm{d}-\mathrm{f}}$ & $18.68^{c}$ \\
\hline $1548 / 08$ & $2.68^{\mathrm{fg}}$ & $19.68^{a-c}$ & $8.23^{\mathrm{fg}}$ & $18.36^{\mathrm{cd}}$ \\
\hline $4311 / 06$ & $2.89^{b}{ }_{-}^{d}$ & $19.41^{c}$ & $7.46^{h}$ & $16.37^{e}$ \\
\hline $4328 / 06$ & $2.50^{\mathrm{h}}$ & $19.53^{b c}$ & $8.32^{\mathrm{e}-\mathrm{g}}$ & $18.42^{c}$ \\
\hline $4330 / 08$ & $2.96^{b}$ & $19.42^{c}$ & $8.68^{\mathrm{cd}}$ & $18.69^{c}$ \\
\hline $4337 / 06$ & $2.70^{\mathrm{e}-\mathrm{g}}$ & $19.85^{a-c}$ & $9.89^{a}$ & $21.12^{\mathrm{a}}$ \\
\hline $4339 / 06$ & $2.87^{b}{ }_{-} e$ & $19.62^{a-c}$ & $9.70^{a}$ & $20.23^{b}$ \\
\hline $5007 / 07$ & $2.84^{b-f}$ & $19.36^{c}$ & $8.74^{\text {cd }}$ & $18.50^{\circ}$ \\
\hline $6702 / \mathrm{A}$ & $2.85^{b-f}$ & $20.31^{a}$ & $9.20^{b}$ & $19.79^{b}$ \\
\hline $6702 / \mathrm{B}$ & $2.94^{b c}$ & $19.79^{a-c}$ & $8.25^{\mathrm{fg}}$ & $18.26^{\mathrm{cd}}$ \\
\hline $6772 / 07$ & $2.78^{\mathrm{c}-\mathrm{f}}$ & $20.26^{a b}$ & $8.57^{\mathrm{c}-\mathrm{e}}$ & $18.42^{c}$ \\
\hline $6787 / 07$ & $3.12^{\mathrm{a}}$ & $19.67^{a-c}$ & $8.72^{\mathrm{cd}}$ & $18.67^{c}$ \\
\hline $6790 / 06$ & $2.94^{b c}$ & $19.95^{a-c}$ & $8.13^{9}$ & $17.53^{d}$ \\
\hline CVL-1 & $2.73^{\mathrm{d}-\mathrm{g}}$ & $20.32^{a}$ & $8.80^{c}$ & $17.86^{\mathrm{cd}}$ \\
\hline CVE-3 & $2.68^{f-g}$ & $19.57^{b c}$ & $8.78^{\mathrm{cd}}$ & $20.42^{\mathrm{ab}}$ \\
\hline $\mathrm{LSD}_{0.05}$ & 0.150 & 0.626 & 0.285 & 0.779 \\
\hline Level of sign & $* *$ & * & $* *$ & $* *$ \\
\hline CV $(\%)$ & 3.11 & 1.90 & 1.95 & 2.49 \\
\hline
\end{tabular}

The ratios of Variability, heritability (h2b), genetic advance (GA) and GA in percent of mean for four yield and its related characters are shown in Table 4 . The phenotypic variance appeared to be higher than the genotypic variance suggested considerable influence of environment on the expression of the genes controlling these traits. The greater percentage of PCV than GCV indicates the presence of considerable variability 
Table 4: Variability, heritability (h2b), genetic advance (GA) and GA in percent of mean for four yield and its related characters of the treatments.

\begin{tabular}{|c|c|c|c|c|c|c|c|c|c|c|c|}
\hline SL. No. & Characters & Minimum & Maximum & Mean & $\begin{array}{c}\text { Genotypic } \\
\text { variance }\left(d^{2} g\right)\end{array}$ & $\begin{array}{c}\text { Phenotypic } \\
\text { variance }\left(d^{2} p\right)\end{array}$ & GCV (\%) & PCV (\%) & $\begin{array}{l}\text { Heritability } \\
\left(h^{2} b\right)\end{array}$ & GA & $G A(\%)$ \\
\hline 1 & Plant height (m) & 2.50 & 3.12 & 2.80 & 0.023 & 0.031 & 5.45 & 6.31 & 74.47 & 0.27 & 9.68 \\
\hline 2 & Base diameter (mm) & 19.36 & 20.32 & 19.76 & 0.057 & 0.197 & 1.21 & 2.25 & 28.93 & 0.26 & 1.34 \\
\hline 3 & Fibre weight/ plant (g) & 7.47 & 9.89 & 8.67 & 0.358 & 0.387 & 6.91 & 7.18 & 92.51 & 1.19 & 13.69 \\
\hline 4 & Stick weight/ plant (g) & 16.37 & 21.12 & 18.75 & 1.38 & 1.60 & 6.26 & 6.74 & 86.40 & 2.25 & 11.99 \\
\hline
\end{tabular}

among the genotypes for the traits. The minimum difference indicated that the environment had less influence on this character expression (Table 4). As the same, Ahsan et al., 2015 [25] revealed that PCV was also higher than GCV.

The considered traits studied in the present investigation showed that the highest heritability was recorded by Fibre weight/ plant (g) $(92.51 \%)$ followed by the Stick weight/plant (g) $(86.40 \%)$ and lowest heritability values was recorded by Base diameter ( $\mathrm{mm}$ (28.93\%). Johnson et al. (1955) [22] suggested that heritability and genetic advance should always be considered jointly during selection of a suitable line or progeny. The GCV and PCV were found to differ significantly for all the fibre yield components and biotic stress factors, which indicated a major role played by the environment in the expression of these characters. This is in agreement with the findings of Sawarkar et. al. (2014) [26].

Simple correlation coefficients between different pairs of characters are presented in Table 5. From the study, we have found that stick weight was positively and significantly correlated with fibre weight.

Cluster analysis was performed using ward's method. The euclidean distance was calculated based on morphological data and a UPGMA dendrogram was produced using the dissimilarity matrix for 15 jute accessions and varieties (Figure 1). Cluster analysis based on morphological traits provides four clusters (Table 6). Clustering pattern showed that cluster II is composed of the highest number of accessions (6), while the other clusters consist of three genotypes each. Cluster III represented highest values of fibre weight/ plant $(\mathrm{g})$ and stick weight/ plant $(\mathrm{g})$. Highest mean of plant height $(\mathrm{m})$ and base diameter $(\mathrm{mm})$ was presented by cluster II and IV respectively (Table 7). A similar of clustering was observed by Roy et. al. (2018) [27] and Roy et. al. (2015) [28], in tossa jute genotypes.

A comparison between cluster means for different traits and relative contribution of the different traits to the total divergence revealed that the accessions with the desirable traits (highest mean values) were distributed into different clusters. Thus from the cluster analysis the treatments 4337/06, 4339/06 and 6702/A were found to be distinct with the desirable characteristics and may be incorporated in breeding programs to improve fibre yield and quality of jute.

\section{DISCUSSIONS}

Recently there are signs of jute regaining its economic importance. With the current consumer demand for reduction
Table 5: Correlation coefficients among four characters in 15 genotypes

\begin{tabular}{lccc}
\hline Characters & $\begin{array}{c}\text { Base diameter } \\
(\mathrm{mm})\end{array}$ & $\begin{array}{c}\text { Fibre weight/ } \\
\text { plant }(\mathrm{g})\end{array}$ & $\begin{array}{c}\text { Stick weight/ } \\
\text { plant }(\mathrm{g})\end{array}$ \\
\hline Plant height $(\mathrm{m})$ & $-0.014^{\mathrm{NS}}$ & $-0.041^{\mathrm{NS}}$ & $-0.202^{\mathrm{NS}}$ \\
Base diameter $(\mathrm{mm})$ & & $0.249^{\mathrm{NS}}$ & $0.079^{\mathrm{NS}}$ \\
Fibre weight/ plant $(\mathrm{g})$ & & & $0.887^{* *}$ \\
\hline
\end{tabular}

** indicates significant at $5 \%$ level of probability, respectability

Table 6: Number, percent and name of accessions in different cluster

\begin{tabular}{lccc}
$\begin{array}{l}\text { Cluster } \\
\text { number }\end{array}$ & $\begin{array}{c}\text { Number of } \\
\text { varieties }\end{array}$ & $\begin{array}{c}\text { Percent } \\
(\%)\end{array}$ & Name of Accessions \\
\hline I & 3 & 20 & Ac 01, Ac 02 and Ac 04 \\
II & 6 & 40 & Ac 03, Ac 05, Ac 08, Ac 10, Ac 12 and \\
& & & Ac 13 \\
III & 3 & 20 & Ac 06, Ac 07 and Ac 15 \\
IV & 3 & 20 & Ac 09, Ac 11 and Ac 14
\end{tabular}

Table 7: Cluster mean for four yield attributing characters of 15 accessions and varieties

\begin{tabular}{lcccc}
\hline Characters & I & II & III & IV \\
\hline Plant height $(\mathrm{m})$ & 2.59 & 2.95 & 2.75 & 2.79 \\
Base diameter $(\mathrm{mm})$ & 19.61 & 19.60 & 19.68 & 20.30 \\
Fibre weight/ plant $(\mathrm{g})$ & 8.34 & 8.34 & 9.46 & 8.86 \\
Stick weight/ plant $(\mathrm{g})$ & 18.49 & 18.00 & 20.59 & 18.69 \\
\hline
\end{tabular}

of the hazardous health and environmental effects of synthetics, there is increasing demand for the use of traditional jute goods, as well as jute in other diversified forms. Natural jute fibres are being substituted increasingly in a range of industries, including paper, celluloid products, non-woven textiles, composites (pseudo-wood), and geotextiles. Geotextiles for example are lightly woven fabrics used to prevent soil erosion, for seed protection, weed control and other agricultural and landscaping purposes. The biodegradable nature of jute is very well suited to this. It is also used to produce climate neutral bags; bags which are committed to reduce $\mathrm{CO}_{2}$. The cellulose in the jute plant produced from the inner woody core or parenchyma of the jute stem could also be used as an effective wood substitute. The recent development of the use of jute in car manufacturing in the automobile industry is example of the kind of huge potential future opportunities there are for use of jute (www.jute.org).

The available variability in a population can be partitioned into genetic parameters such as coefficients of variation of genotypic and phenotypic, heritability and genetic advance to serve as basis for selection of desirable genotypes in a breeding program. From our study, we have found yield attributing characters varies 


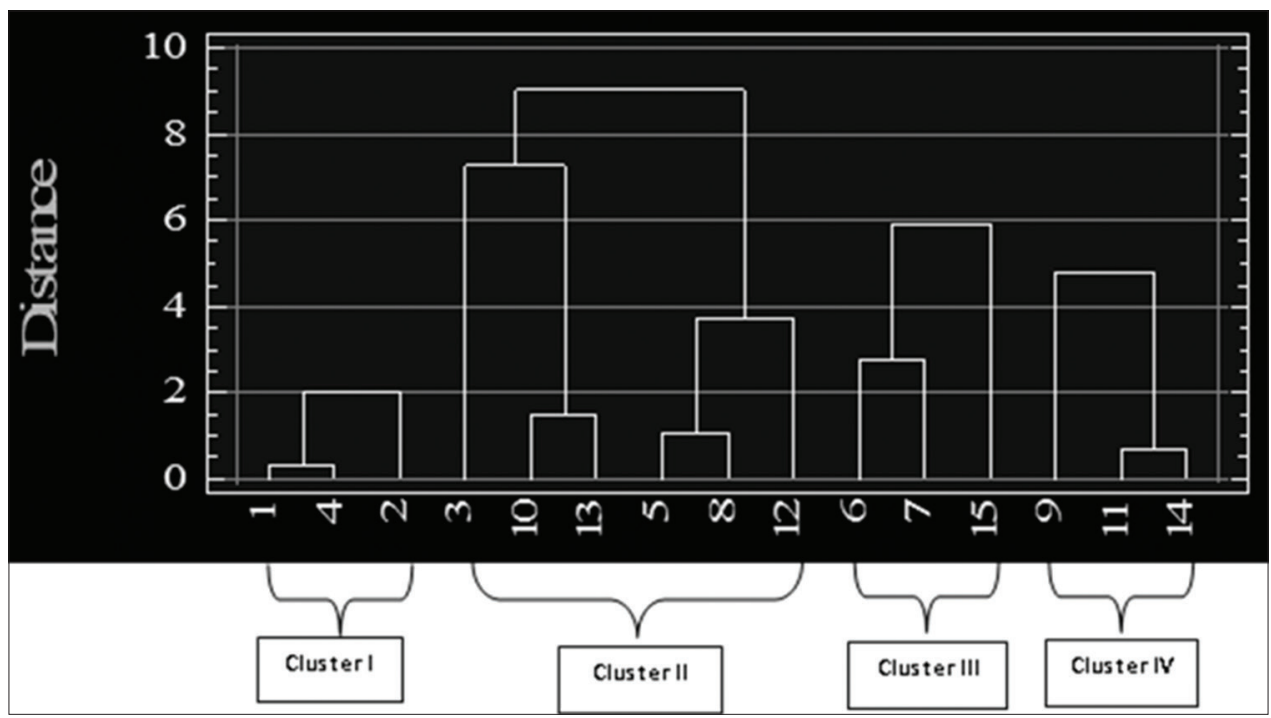

Figure 1: Dendrogram based on summarized data on differentiation among 15 accessions landraces according to Ward's method

significantly in different progenies. There are certain treatments that showed visually high yielding result than that of the original check varieties. The result showed significant difference among the treatments for plant height and fibre weight. Treatment number 4337/06, 6702/A and 4339/06 gave higher yield than both the check varieties CVL-1 and CVE-3.

\section{CONCLUSION}

Having a good selection of traits for selecting the desired genotypes within the planned breeding program, knowledge of the nature and degree of variation in available breeding material, the component properties' relationship to fiber performance and contribution, and their direct and indirect effects are very important.

The present study was visualized to divulge the nature and magnitude of genetic variability, the pattern of character association among the characters, the direct and indirect effects of component characters towards fiber yield and the degree of genetic divergence in germplasm accessions of deshi jute. The material for the present study comprised of thirteen progenies of jute (Corchorus capsularis L.) collected from BJRI, were evaluated using RCBD design for different quantitative characters. The analysis of variance showed significant differences among the genotypes for almost all the characters and from our study, we can insist that treatment number 4337/06, 6702/A and 4339/06 were found to be distinct with the desirable characteristics and may be incorporated in breeding programs to improve fibre yield and quality of jute.

\section{REFERENCES}

1 Wild H. Corchorus. In: Leistner OA (ed) Flora of Southern Africa 21 (1: Tiliaceae). Department of Agriculture, Botanical Research Institute, Pretoria. 1984;32-42.

2 Edmonds JM. Herbarium survey of African Corchorus L. species. Systematic and Ecogeographic Studies on Crop Genepools 4. International Board for Plant Genetic Resources, Rome; 1990.
3 Heywood VH, Moore DM, Richardson IBK and Stearn WT. Flowering plants of the world (No. 582.13 F644). Oxford University Press; 1993.

$4 \quad$ Kubitzki $\mathrm{K}$ and Bayer $\mathrm{C}$. The families and genera of vascular plants. V. Malvales, Capparales and non-betalain Caryophyllales. 2003.

5 Basu A, Ghosh M, Meyer R, Powell W, Basak SL and Sen SK. Analysis of genetic diversity in cultivated jute determined by means of SSR markers and AFLP profiling. Crop Science. 2004;44(2):678-85.

6 Xiong HP. Breeding sciences of bast and leaf fiber crops. Chinese Agricultural Science and Technology Press, Beijing. 2008;319-41.

7 Mir RR, Rustgi S, Sharma S, Singh R, Goyal A, Kumar J, Gaur A, Tyagi AK, Khan H, Sinha MK and Balyan HS. A preliminary genetic analysis of fibre traits and the use of new genomic SSRs for genetic diversity in jute. Euphytica. 2008;161(3):413-27.

8 Chen Y, Zhang L, Qi J, Chen H, Tao A, Xu J, Lin L and Fan P. Genetic linkage map construction for white jute (Corchorus capsularis L.) using SRAP, ISSR and RAPD markers. Plant Breeding 2014;133(6):777-81.

9 Ghosh RK, Wongkaew A, Sreewongchai T, Nakasathien S and Phumichai C. Assessment of genetic diversity and population structure in jute (Corchorus spp.) using simple sequence repeat (SSR) and amplified fragment length polymorphism (AFLP) markers. Agriculture and Natural Resources. 2014;48(1):83-94.

10 Wazni MW, Islam AS, Taliaferro JM, Anwar N and Sathasivan K. Novel ESTs from a jute (Corchorus olitorius L.) cDNA library. Plant Tissue Culture and Biotechnology. 2007;17(2):173-82.

11 Zhang G, Qi J, Xu J, Niu X, Zhang Y, Tao A, Zhang L, Fang P and Lin L. Overexpression of UDP-glucose pyrophosphorylase gene could increase cellulose content in Jute (Corchorus capsularis L.) Biochemical and Biophysical Research Communications. 2013;442(34): 153-58.

12 FAO. STATISTICS; for Jute, Kenaf, Sisal, Abaca, Coir and Allied Fibres. Rome: Food and Agriculture Organization (FAO); 2014.

13 Bangladesh Bureau of Statistics. The Year Book of Agricultural Statistics of Bangladesh. Statistics Division Ministry of Planning, Government Peoples Republic of Bangladesh, Dhaka;2017.

14 Akter $\mathrm{N}$ and Bhuiyan MSH. Screening of germplasm for higher fibre yield and desirable traits of tossa jute. Annual Research Programme. Agricultural Research on Jute. 2016;17.

15 Joshua DC and Thakare RG. Inheritance of induced mutant characters in jute (Corchorus capsularis L.). Current Science. 1984;53(13):697-00.

16 Tomooka N. Genetic diversity and land race differentiation of mungbean, Vigna radiate (L) wilczek, and evaluation of its wild relatives (The subgenus ceratotropics) as breeding materials. Technical Bull, Tropical Res. Center. Japan. 1991;28:1-4.

17 Sherestha VS. Genetic variability, correlation and path analysis studies in jute (Doctoral dissertation, MS thesis submitted to Rajendra Agricultural University, Bihar, Pusa, India); 1991.

18 Jayamani P, Negrao S, Martins M, Macas B and Oliveira MM. Genetic relatedness of Portuguese rice accessions from diverse origins as 
assessed by microsatellite markers. Crop Science. 2007;47(2):879-84.

19 Al-Jibouri H, Miller PA and Robinson HF. Genotypic and environmental variances and covariances in an upland Cotton cross of interspecific origin 1. Agronomy Journal. 1958;50(10):633-36.

20 Burton GW. Quantitative inheritance in grasses. Pro VI Int Grassl Cong. 1952:277-83.

21 Hanson $\mathrm{CH}$, Robinson HF and Comstock RE. Biometrical studies of yield in segregating populations of Korean lespedeza 1. Agronomy journal. 1956;48(6):268-72.

22 Johnson HW, Robinson HF and Comstock RE. Estimates of genetic and environmental variability in soybeans 1 . Agronomy journal. 1955;47(7):314-18.

23 Singh RK, Chaudhary BD. Biometrical methods of quantitative genetic analysis. Haryana Journal of Horticulture Science. 1985;12(2): 151-56.

24 Arju Miah et. al.Characterization of Deshi Jute (Corchorus capsularis) Germplasm Collected from Different Sources. Acta Scientific Microbiology. (2020); 4.7 :173-80.
25 Ahsan MZ, Majidano MS, Bhutto $H$, Soomro AW, Panhwar FH, Channa AR and Sial KB. Genetic variability, coefficient of variance, heritability and genetic advance of some Gossypium hirsutum L. accessions. Journal of Agricultural Science. 2015;7(2):147.

26 Sawarkar ASHUTOSH, Yumnam SONIKA, Patil SG and Mukherjee S. Correlation and path coefficient analysis of yield and its attributing traits in tossa jute (Corchorus olitorius L.). The Bioscan. 2014;9(2):883-87.

27 Roy SK, Chakraborty M, Hijam L, Mondal HA, Surje DT, Roy A, Mondal A, Pal A, Kundu A, Das S Sarker P, Kheoar S, Chakraborty G, Mitra S. Studies on genetic variability and screening for fibre yield components and biotic stress factors in tossa jute (Corchorus olitorius L.) germplasm under Terai region of West Bengal Electronic Journal of Plant Breeding. 2018;9 (2):409-23.

28 Roy SK, Karmakar PG, Bhaduri SK, Das B, Kale VA, Haque, S. Genetic diversity, variability and correlation study in tossa jute (Corchorus olitorius L.). Indian Journal of Natural Fibres. 2015;1(2):225-32. 